\title{
ROBO4 Gene
}

National Cancer Institute

\section{Source}

National Cancer Institute. ROBO4 Gene. NCI Thesaurus. Code C74444.

This gene plays a role in blood vessel development and maturation. 